\title{
EFFECT OF GRAFTING ON THE CUCUMBER YIELD AND QUALITY UNDER HIGH AND LOW TEMPERATURES. \\ El-Sayed, S.F. ${ }^{1}$ H.A. Hassan; A.A Abdel-Wahab ${ }^{1}$ and A.A. Gebrael ${ }^{2}$ \\ 1-Vegetable Crops Department, Faculty of Agriculture, Cairo University, Giza \\ 2- Minstery of Agriculture - Horticulture Department- Kurdistan Reigen - Iraq
}

\begin{abstract}
Two experiments were conducted during the summer and winter seasons of 2013 to study the effect of grafting using different rootstocks on the yield and quality and chemical analysis of cucumber (Cucumis sativus L.) cultivar "Hady" under high and low temperatures. The experiments consisted of 5 treatments, 4 rootstocks, namely Bottle Gourd (Lagenaria siceraria Standl.), Supper Shintosa (Cucurbita maxima Duchesne $\times$ Cucurbita moschata Duchesne), Squash 3 (Cucurbita pepo) and Ferro' (C. maxima $\times$ C. moschata), in addition to non-grafted control. Data were recorded on plant length and physical characters of fruits 30,60 and 90 days after planting, early and total yield $/ \mathrm{m} 2$, chemical characters (percentage of dry matter, TSS and total and reducing sugars) of cucumber fruits and percentage of N, P and K in cucumber leaves. The results indicated that Ferro rootstock increased plant height, physical characters, early and total yield of cucumber fruits in both summer and winter seasons, as compared with non-grafted control. No significant effect was detected from using rootstocks on $\mathrm{N}, \mathrm{P}$ and $\mathrm{K}$ percentage in cucumber leaves, except grafting cucumber on Bottle Gourd rootstock which significantly increased N\% only in the winter season. Chemical contents of cucumber fruits were not affected by grafting in summer season, while Bottle Gourd increased total sugars and Ferro rootstock caused significant increase in the percentage of dry matter and reducing sugars in winter season as compared with non grafted plants.
\end{abstract}

\section{INTRODUCTION}

Grafting was traditionally used to refine woody plants, but since more than 50 years it is applied also in herbaceous fruit vegetables to enhance the tolerance of elite cultivars to biotic and abiotic stress conditions (Lee et al., 2010; Flores et al., 2010; Rouphael et al., 2010). In Japan, Korea, the Mediterranean basin, and several European countries, grafting of cucurbits (e.g.,cucumber, melon, and watermelon) has become a common practice. As with other vegetables, the main purpose of employing this technology in cucurbits is to control Fusarium wilt and other soil borne diseases (Crinò et al.2007, Lee et al., 2010). Grafting restricts input of agrochemicals against soil borne pathogens and is, therefore, considered an environment friendly cultivation technique, which is strongly recommended for integrated crop management systems (Rivard and Louws 2008). However, the impact of grafting on cucurbits includes not only stronger resistance against pathogens but also a higher tolerance to abiotic stress conditions such as salinity, heavy meta, nutrient stress, thermal stress, water stress, organic pollutants, and 
alkalinity (Colla et al., 2010a,b,c and,2011; Rouphael et al. 2008 a,b; Savvaset al., 2009, 2010; Schwarz et al.,2010).

Because of its low-temperature sensitivity, which includes numerous physiological disorders under suboptimal temperatures, cucumber is either cultivated year-round indoors in greenhouses or as a typical summer crop outdoors in summer. The production of cucumber in plastic houses becomes very low during the coldest months in Egypt (Januray and February). To solve this problem in greenhouses in European countries are heated in winter months. Due to secrecy of energy and increasing energy prices in addition to world concern about environmental problems related with $\mathrm{CO} 2$ emissions from the combustion of fossil fuel, heating solution is not economic. A simple option to decrease the greenhouse temperature is the breeding of new cultivars that are better adapted to low temperatures. As a fast alternative for the relatively slow breeding process aimed to lower the energy demand of tomato, grafting of existing elite commercial cultivars onto selected rootstocks is regarded as a promising tool (Heuvelink and Kierkels, 2005).

Many investigators reported that cucumber plants grafted onto Cucurbita ficifolia could be used for widespread cucumber production, as the grafted plants were more vigorous than the non grafted ones and had increased of shoot fresh weight under protected cultivation (Shimada and Moriya, 1977; Nijs, 1984; Eguchi and Koutaki, 1986;; Wenget al., 1993; El-Aidyet al., 1996).

Grafting cucumber plants onto Cucurbita ficifolia rootstock grew faster (Nijs, 1980), had higher values of plant fresh weight (Nijs, 1984;) and were more vigorous (Eguchi and Koutaki 1986)than non-grafted ones. Under low temperature conditions, grafting cucumber on Cucurbita ficifolia rootstock increased stern length, leaf number, and leaf area of the scions as compared with non-grafted plants (Nijs, 1984).Also, grafting cucumber on Cucurbita ficifolia had better growth than non-grafted plants under partially shaded and humid plastic houses conditions in midsummer (Lee 1989).Similarly, El-Aidyet al. (1996) studied the effect of grafting on vegetative growth of cucumber plants under plastic house. They found that grafted plants onto Cucurbita ficifolia had longer stems, more leaves, larger leaf area and higher fresh and dry weights than non-grafted ones.

Kabeel (1999) studied the effect of cut grafting method using fig leaf gourd, bottle gourd, pumpkin (Cucurbit amoschata), squash and non-grafted cucumber "Pasandra F1" on vegetative growth. He found that fig leaf gourd and bottle gourd had the most promotive effect on plant length in autumn growing season, while the fig leaf gourd and pumpkin rootstocks had the most increasing effect on plant length in spring plantation. However, all used rootstocks had no significant effect on number of leaves per plant. The fig leaf gourd and bottle gourd as rootstocks showed the highest values of leaf area and fresh and dry weights of plant compared with the other used rootstocks or the control. In another study, Abd-Alla (2002) grafted cucumber plants Nile cv. , onto squash, pumpkins (Cucurbitalmoschata), pumpkin (C. maxima), bottle gourd, fig leaf gourd and non-grafted cucumber and found that the plants grafted onto fig leaf gourd and bottle gourd had the highest values of stem length, number of leaves, leaf area and fresh and dry weights of 
leaves compared with the other used rootstocks or the non-grafted ones. On the other hand, when Huaifu et al. (2006) investigated the growth of cucumber (Cucumis sativus) grafted on smooth luffa(Luffalcylindrica [ $L$. aegyptiacap) compared with self-rooted plants they found that cucumber grafted on smooth luffa showed significantly higher values for the plant height; stem thickness and fresh and dry mass of grafted seedlings compared to non-grafted plants

Increases in yield early were reported due to grafting cucumber onto Cucurbitaficifolia (Nijs, 1980) fig leaf gourd and pumpkin (Kabeel,1999) squash, pumpkin (C. moschata), pumpkin2 (C. maxima) bottle gourd and leaf gourd rootstocks (Abd-Alla ,2002), compared with the non-grafted plants.

Several reports indicated that cucumber grafting could be used for increase total yields. This was proved due to grafting onto C. ficifolia (Tsambanakis , 1984), Sicyosa ngulatus rootstock (Visser and Nijs ,1987), fig leaf gourd and pumpkin (Kabeel ,1999), squash, pumpkin (C. moschata), pumpkin2 (C. maxima) bottle gourd and leaf gourd rootstocks (Abd-Alla ,2002) and Lagenariasiceraria, Cucurbita ficifolia, C. maxima, Benincasa hispida and C. pepo (Fedorovet al., 2005).

The quality of cucumber fruits was found to be affected by grafting. In this regard, kabeel (1999) and Abd-Alla (2002) found that grafting cucumber onto pumpkin or squash led to raise TSS\% of fruits. On the contrary, Hongli et al. (2003) recorded negative effect for grafting, where contents of soluble sugar, vit. C, amino acids particularly, glutamic and aspartic acids decreased and the contents of nitrate, tannititrable acid increased in the grafted cucumber on fig leaf gourd (Cucurbitcificifolia) and Sintozwa(Cucurbita maxima $x$ C.' moschata). Other studies suggested that grafting (rootstock) has no significant effect on fruit dry matter and soluble sugar content of cucumber under unstressed conditions (Zhu et al., 2006a,b; Zhong and Bie, 2007).

Contradictory results were recorded concerning effect of grafting on mineral contents of cucumber plants. While grafting led to increase in N, p and K in a study (El-Aidy et al.1996), it increased $\mathrm{N}$ and $P$ only and showed no constant trend on the $K$ content in cucumber leaves in another study (Abd-Alla 2002). In contrast,..Canizares et al. (2005) stated that grafting cucumber did not affect $\mathrm{N}$ and $\mathrm{P}$ contents, but grafted plants had higher $\mathrm{K}$ content in plant shoots compared to nongrafted ones.

The present investigation aimed to study the effect of grafting using different rootstocks on the cucumber yield and quality under high and low temperatures.

\section{MATERIAL AND METHODS}

Two experiments were conducted during the summer and winter seasons of 2013 to study the effect of grafting using different rootstocks on 
the yield and quality and chemical analysis of cucumber (Cucumis sativus L.) cultivar Hady under high and low temperatures. The summer season experiment was carried out in clay soil in net house at the experimental station, Faculty of Agriculture, University of Cairo, while the winter experiment was conducted in sandy soil in plastic house in a private farm located in Aiat, Giza Governorate, Egypt.

Treatments

Five treatments were used, i.e. four grafting rootstocks and control treatment (without grafting).

\section{Rootstocks:}

The rootstocks used were as follows:

1. Bottle Gourd (Lagenaria siceraria Standl.), obtained from local markets

2. Supper Shintosa (Cucurbita maxima Duchesne×Cucurbita moschata Duchesne, JSI, Holland)

3. Squash 3 (Cucurbita pepo, Sakata Japan),

4. Ferro (C. maxima $\times$ C. moschata, Reck Zoan, Holland)

\section{Grafting method}

Cut (hole insertion) grafting method was used according, to the methods described by Kawaide (1985)

1. Rootstock seeds were also sown in (84 eyes) filled with a mixture of peat Moss: vermiculite $(1: 1 \mathrm{v} / \mathrm{v})$ under plastic house on $27^{\text {th }}$ February 2013 (for summer planting) and on $20{ }^{\text {th }}$ October 2013 (for winter planting) , while cucumber scion seeds were also sown in seedling foam trays (84 eyes) filled with the same medium of rootstocks but on $9^{\text {th }}$ March 2013(for summer planting) and $10^{\text {th }}$ November 2013(for winter planting)

2. After germination and appearance of the first true leaf of rootstock seedlings, they were located in $10 \mathrm{~cm}$ back plastic bags, containing the same mixture of peat Moss and vermiculite $(1: 1 \mathrm{v} / \mathrm{v})$, supplemented with $50 \mathrm{~g}$ of a fungicide for each $50 \mathrm{~kg}$ of the mixture.

3. Seedling of rootstocks and the scions were ready for grafting at the appearance of the second true leaf on $25^{\text {th }}$ March 2013and on $25^{\text {th }}$ November 2013, for summer and winter plantings, respectively.

4. Seedlings of rootstocks were picked between the two cotyledons after removing the top of the seedling with a razor blade, creating a $V$-shaped cut between the cotyledons. An inverse V-shaped cut was made on the stem of the scion, $2 \mathrm{~cm}$ below the cotyledons, to fit the cut in the rootstock. Scion and rootstocks were held with a grafting clip.

5. The seedlings were placed under plastic tunnel for optimum temperature and humidity.

6. The compatibility was determined after 7 days in relatively high temperature $25-30^{\circ} \mathrm{C}$ and 10 days in relatively low temperature $20-25^{\circ} \mathrm{C}$, from conducting after grafting stage watching the new growth on the scions.

7. The plastic tunnel was gradually opened for adaptation and preparing the grafting seedlings for transplanting in the plastic house. 
Transplants of grafted and non-grafted cucumber were planted in net house greenhouse on $10^{\text {th }}$ April 2013 and plastic house on $14^{\text {th }}$ December 2013, for summer and winter planting, respectively. The treatments were set in three replicates; each contained 30 plants on both sides of $120 \mathrm{~cm}$ width rows at $50 \mathrm{~cm}$ apart, between the plants within each side. The plants were irrigated using drip irrigation lines and fertilized with $1 \mathrm{~m}^{3}$ farm yard manure, $22 \mathrm{~kg} \mathrm{~N}, 9 \mathrm{~kg} \mathrm{P} \mathrm{O}_{5}$ and $25 \mathrm{~kg} \mathrm{~K} \mathrm{O}_{2} / 100 \mathrm{~m}^{2}$. Other cultural practices; such as plant protection against weeds, diseases and insects; were performed whenever they were thought to be necessary as recommended for commercial cucumber production under protected cultivation.

Data Recorded:

Data were recorded on 10 plants in the middle of each treatment on the following characteristics of cucumber plants:-

1- Plant height (cm) It was determined 30,60 and 90 days after transplanting.

2- Yield

1.1. Early yield:

It was estimated as the weight of fruits for all harvested fruits of the first 4 pickings.

2.2. Total yield:

Data of total yield included weight of fruits all over the harvesting season.

2. Physical characters of fruits (30,60 and 90 days after transplanting).:

3.1. Average fruit weight

3.2. Average fruit diameter

3.3. Average fruit length

3. Chemical characters of cucumber fruits ( 60 days after planting).

4.1. Dry matter $\%$

4.2. Total soluble solids TSS content

4.3. Total and reducing sugars in cucumber fruits.

4. Mineral contents of leaves:

$\mathrm{N}, \mathrm{P}$ and $\mathrm{K}$ contents of leaves.

Methods of chemical analysis

1. Mineral nutrients content ( $\mathrm{N}, \mathrm{P}$ and $\mathrm{K} \%$ ):

Dry matter samples of leaves were ground in a Willy mill and

kept for $\mathrm{N}, \mathrm{P}$ and $\mathrm{K}$ determinations. The dry material was wet digested with sulphuric acid-hydrogen peroxide mixture as described by Koch and McMeeking, (1924) and Lowther, (1980). Total N, P and K was determined according to the following methods:

1.1 Total nitrogen; was determined in the digestion product using the micro Kjeldahl method (Pregel, 1945).

1.2 Total phosphorus; was determined, colorimetrically, using a spectrophotometer at 650 1.un (Frie et al., 1964 and King, 1951).

1.3. Total potassium; was determined using flame photometer (Jackson, 1967).

2. Total soluble solids content (TSS \%):

It was estimated in fruit juice by using a hand refractometer 
3. Dry matter percentage of fruit flesh:

It was determined by allowing $100 \mathrm{~g}$ of fruit flesh to dry in an oven at $70^{\circ} \mathrm{C}$ till constant weight.

4. Reducing and non-reducing sugars:

They were determined of each fruit samples according to Malik and

Singh (1980) method. Sugars were extracted from $0.5 \mathrm{~g}$ ground dried material by distilled water, and then determined by phenol sulfuric method and nelson arsenste-molibdate colorimetric method for total and reducing sugars, respectively. The non-reducing sugars were calculated by the difference between total and reducing sugars.

The experimental design and statistical analysis:

The experimental design was a completely randomized design (CRD) with three replicateo. All recorded data were statistically analyzed according to the method described by Little and Hills (1972). Revised Least significant difference test was used for the comparison among treatment's means (Gomez and Gomez, 1984)

\section{RESULTS AND DISCUSSION}

\section{1- Effect of rootstock types on plant height at different plant stages}

Results in Table 1 indicated that all rootstocks in the summer season, except squash 4, Super Shintosa, and in Bottle Gourd, 30, 60 and 90 days after planting, respectively, showed higher values of plant height, as compared with the control. On the other hand, using any rootstock in winter caused significant increase in plant height over non-grafted control. It was also clear that Ferro was the most superior rootstock in the respect of stimulative effect on plant height in both summer and winter plantings.

These results may be attributed to the strength roots of rootstocks that permit better growth. Similar results were found by Shimada and moriya, (1977); Nijs, 1984; Eguchi and Koutaki, 1986; Kim and Lee, 1989; Wenget al., (1993); El-Aidyet al., (1996) who reported that cucumber plants grafted onto Cucurbita ficifolia could be used for widespread cucumber production, as the grafted plants were more vigorous than the non grafted ones and had increased of shoot fresh weight under protected cultivation. Similarly, El-Aidy et al. (1996) studied the effect of grafting on vegetative growth of cucumber plants under plastic house. They found that grafted plants onto Cucurbita ficifolia had longer stems, more leaves, larger leaf area and higher fresh and dry weights than non-grafted ones. Kabeel (1999) studied the effect of cut grafting method using fig leaf gourd, bottle gourd, pumpkin (Cucurbita moschata), squash and nongrafted cucumber Pasandra F1 on vegetative growth. He found that figleaf gourd and bottle gourd had the most stimulative effect on plant length in autumn growing season, while the figleaf gourd and pumplc in rootstocks had the most increasing effect on plant length in spring plantation. The figleaf gourd and bottle gourd as rootstocks showed the highest values of leafa rea and fresh and dry weights of plant compared with the other used rootstocks or the control. In another study, Abd-Alla (2002) grafted cucumber plants Nile cv. , onto squash, pumpkins (Cucurbita moschata), pumpkin (C. maxima), bottle 
gourd, figleaf gourd and non-grafted cucumber and found that the plants grafted onto figleaf gourd and bottle gourd had the highest values of stem length, number of leaves, leaf area and fresh and dry weights of leaves compared with the other used rootstocks or the non-graftedones.On the other hand, when Huaifu et al. (2006) investigated the growth of cucumber (Cucumis sativus) grafted on smooth luffa (Luffa cylindrica [L. aegyptiaca) compared with self-rooted plants they found that cucumber grafted on smooth luffa showed significantly higher values for the plant height; stem thickness and fresh and dry mass of grafted seedlings compared to nongrafted plants.

Table 1: Effect of grafting on plant height 30,60 and 90 days after planting (summer and winter plantings, 2013)

\begin{tabular}{lcccccc}
\hline & \multicolumn{3}{c}{ Summer planting } & \multicolumn{3}{c}{ Winter planting } \\
\hline Rootstock & 30 day & 60 day & 90 day & 30 day & 60 day & 90 day \\
\hline Bottle Gourd & 65.00 & 66.00 & 113.30 & 40.33 & 80.33 & 135.00 \\
Super Shintosa & 57.00 & 63.67 & 164.00 & 43.33 & 108.00 & 150.00 \\
Squash 3 & 48.33 & 66.67 & 156.30 & 37.33 & 87.00 & 143.70 \\
Ferro & 69.33 & 69.67 & 196.50 & 51.00 & 118.30 & 163.00 \\
LSD at 0.05 & 7.54 & 5.52 & 7.34 & 5.44 & 8.03 & 11.08 \\
\hline
\end{tabular}

\section{2- Effect of rootstock types on $\mathrm{N} \%, \mathrm{P} \%$ and $\mathrm{K} \%$ in cucumber leaves}

As shown in Table 2, there were no significant differences between control plants and grafted cucumber on all rootstocks in N\% in the summer season and $\mathrm{P} \%$ and $\mathrm{K} \%$ in both seasons. On the other hand, grafting cucumber on Bottle Gourd rootstock significantly increased N\% in the winter season as compared with control. Contradictory results were recorded concerning effect of grafting on mineral contents of cucumber plants. While grafting led to increase in N, P and K in the study of El-Aidyet al. (1996 ), grafting increased $\mathrm{N}$ and $\mathrm{P}$ and showed no constant trend on the $\mathrm{K}$ content in cucumber leaves in the study of Abd-Alla (2002). In contrast, Canizareset al. (2005) stated that grafting cucumber did not affect $\mathrm{N}$ and $\mathrm{P}$ contents, but grafted plants had higher $\mathrm{K}$ content in plant shoots compared to non-grafted ones. The contradiction in different results may be attributed to using different rootstocks under different conditions.

Table 2: Effect of grafting on the percentage of nitrogen, phosphorus and potassium in cucumber (summer and winter plantings, 2013)

\begin{tabular}{|c|c|c|c|c|c|c|}
\hline \multicolumn{4}{|c|}{ Summer planting } & \multicolumn{3}{|c|}{ Winter planting } \\
\hline Rootstock & $\mathrm{N} \%$ & $\mathrm{P} \%$ & $\mathrm{~K} \%$ & $\mathrm{~N} \%$ & $\mathrm{P} \%$ & $\mathrm{~K} \%$ \\
\hline Bottle Gourd & 3.94 & 0.67 & 3.15 & 4.46 & 0.66 & 2.48 \\
\hline Super Shintosa & 3.80 & 0.57 & 3.15 & 3.90 & 0.68 & 2.18 \\
\hline Squash 3 & 3.74 & 0.92 & 3.17 & 3.92 & 0.59 & 2.90 \\
\hline Ferro & 3.36 & 0.91 & 3.45 & 3.85 & 0.67 & 2.97 \\
\hline Non-grafting & 4.27 & 0.62 & 3.63 & 3.54 & 0.47 & 2.75 \\
\hline LSD at 0.05 & N.S & N.S & N.S & 0.91 & N.S & N.S \\
\hline
\end{tabular}


3 Effect of rootstock types on some physical characteristics of cucumber fruits:

Data presented in Tables 3, 4 and 5 clearly indicated that grafting on Ferro rootstock showed the most supper effect on physical characters of fruits as it led to remarkable increase in physical characters of cucumber fruits in summer season as compared with non-grafted control. Such increase was significant regarding length and diameter of fruits at all stages and average fruit weight 30 and 60 days after planting. On the other hand, grafting on Squash 3 rootstock also significantly increased weight of fruits 30 and 60 days after planting, and fruit diameter 60 and 90 days after planting.

Table 3: Effect of grafting on physical characters of cucumber fruits, 30 days after planting (summer planting, 2013)

\begin{tabular}{|c|c|c|c|}
\hline Rootstock & $\begin{array}{l}\text { Fruit weight } \\
\text { (g) }\end{array}$ & $\begin{array}{l}\text { Fruit length } \\
\text { (cm) }\end{array}$ & $\begin{array}{l}\text { Fruit diameter } \\
(\mathrm{mm})\end{array}$ \\
\hline Bottle Gourd & 64.00 & 13.17 & 27.00 \\
\hline Super Shintosa & 58.50 & 12.00 & 25.83 \\
\hline Squash 3 & 70.00 & 12.50 & 25.50 \\
\hline Ferro & 70.67 & 15.00 & 30.17 \\
\hline LSD at 0.05 & 6.88 & 1.70 & 3.37 \\
\hline
\end{tabular}

Table 4; Effect of grafting on physical characters of cucumber fruits, 60 days after planting (summer planting, 2013)

\begin{tabular}{lccc}
\hline Rootstock & $\begin{array}{c}\text { Fruit weight } \\
\text { (g) }\end{array}$ & $\begin{array}{c}\text { Fruit length } \\
\text { (cm) }\end{array}$ & $\begin{array}{c}\text { Fruit diameter } \\
\text { (mm) }\end{array}$ \\
\hline Bottle Gourd & 66.00 & 12.00 & 26.17 \\
Super Shintosa & 63.67 & 14.00 & 24.17 \\
Squash 3 & 66.67 & 13.00 & 27.50 \\
Ferro & 69.67 & 14.17 & 31.17 \\
L. S. D. at 0.05 & 5.52 & 2.08 & 5.56 \\
\hline
\end{tabular}

Table 5: Effect of grafting on physical characters of cucumber fruits, 90 days after planting (summer planting, 2013)

\begin{tabular}{lccc}
\hline Rootstock & $\begin{array}{c}\text { Fruit weight } \\
\text { (g) }\end{array}$ & $\begin{array}{c}\text { Fruit length Fruit diameter } \\
\text { (cm) }\end{array}$ & $\begin{array}{c}\text { (mm) } \\
\text { Bottle Gourd }\end{array}$ \\
\hline Super Shintosa & 66.33 & 13.33 & 26.83 \\
Squash 3 & 63.67 & 13.00 & 23.50 \\
Ferro & 67.50 & 13.00 & 27.00 \\
L. S. D. at 0.05 & 69.00 & 15.00 & 30.50 \\
\hline
\end{tabular}

Ferro rootstock caused significant increase in cucumber fruit weight, diameter and length in winter in all plant stages, except fruit length after 60 days from planting as compared with non grafted plants. Squash 3 also caused significant increase in fruit weight and diameter 30 days after planting, fruit weight 60 days after planting as well as fruit lengh and diameter, 90 days after 
planting as compared with non-grafted control (Table 6, 7 and 8). Data presented in these tables also indicted that average fruit weight, 30 days after planting and fruit diameter, 60 days after planting were increased due to grafting on Super Shintosa, as compared with the control treatment. The present results revealed the superiority effect of "Ferry" rootstock, followed by Squash 3 over the other rootstocks and non grafted control on the physical characters of cucumber fruits under both summer and winter plantings.

Table 6: Effect of grafting on physical characters of cucumber fruits, 30 days after planting (winter planting, 2013/2014)

\begin{tabular}{lccc}
\hline Rootstock & $\begin{array}{c}\text { Fruit weight } \\
(\mathbf{g})\end{array}$ & $\begin{array}{c}\text { Fruit length } \\
\text { (cm) }\end{array}$ & $\begin{array}{c}\text { Fruit diameter } \\
(\mathbf{m m})\end{array}$ \\
\hline Bottle Gourd & 59.67 & 11.83 & 22.67 \\
Super Shintosa & 64.67 & 12.17 & 22.67 \\
Squash 4 & 68.67 & 12.50 & 25.67 \\
Ferro & 68.67 & 15.17 & 25.67 \\
Non-grafting & 50.67 & 12.17 & 21.67 \\
\hline L. S. D. at 0.05 & 9.38 & 1.57 & 2.56
\end{tabular}

Table 7: Effect of grafting on physical characters of cucumber fruits, 60 days after planting (winter planting, 2013/2014)

\begin{tabular}{lccc}
\hline Rootstock & Fruit weight (g) & $\begin{array}{c}\text { Fruit length } \\
\text { (cm) }\end{array}$ & $\begin{array}{c}\text { Fruit diameter } \\
\text { ( } \mathbf{m m})\end{array}$ \\
\hline Bottle Gourd & 64.00 & 12.33 & 24.67 \\
Super Shintosa & 61.67 & 13.00 & 25.67 \\
Squash 4 & 66.67 & 12.67 & 24.00 \\
Ferro & 68.67 & 15.00 & 24.00 \\
L. S. D. at 0.05 & 4.63 & 2.00 & 1.96 \\
\hline
\end{tabular}

Table 8: Effect of grafting on physical characters of cucumber fruits, 90 days after planting (winter planting, 2013/2014)

\begin{tabular}{lccc}
\hline Rootstock & $\begin{array}{c}\text { Fruit weight } \\
\text { (g) }\end{array}$ & $\begin{array}{c}\text { Fruit length Fruit diameter } \\
\text { (cm) }\end{array}$ & $\begin{array}{c}\text { (mm) } \\
\text { (m) }\end{array}$ \\
\hline Bottle Gourd & 62.67 & 12.00 & 21.33 \\
Super Shintosa & 65.33 & 14.00 & 24.00 \\
Squash 4 & 65.00 & 14.33 & 26.00 \\
Ferro & 69.00 & 15.00 & 27.33 \\
L. S. D. at 0.05 & N.S. & 1.62 & 2.89 \\
\hline
\end{tabular}

3- Effect rootstock types on early and total yield of cucumber:

Data presented in Table 9 showed that early yield in both seasons and total yield in the summer season were significantly higher than the control when cucumber was grafted onto Ferro and Squash 3 rootstocks, while the total yield significantly way increased only in the winter season when cucumber scion was 
grafted on Ferro rootstock as compared with control. The superior effect of the rootstocks Ferro and Squash 3 on cucumber yield in the present study is attributed to their positive effect on average fruit weight, length and diameter (Tables 2 - 8). In this respect, several reports indicated that cucumber grafting could be used for increase total yield. This was proved due to grafting onto C. ficifolia (Tsambanakis, 1984), Sicyosangulatusrootstock (Visser and Nijs ,1987) figleaf gourand pumpkin (Kabeel ,1999) squash, pumpkin (C. moschata), pumpkin2 (C. maxima) bottle gourd and leaf gourd rootstocks (Abd-Alla, 2002) and Lagenaria siceraria, Cucurbita ficifolia, C. maxima, Benincasa hispida and C. pepo (Fedorovet al., 2005).

Table 9: Effect of grafting on early and total yield $(\mathrm{kg} / \mathrm{m} 2)$ of cucumber (summer and winter plantings, 2013)

\begin{tabular}{lcccc}
\hline \multicolumn{4}{c}{ Summer plant } & \multicolumn{2}{c}{ winter plnat } & \\
\hline Rootstock & Early yield & Total yield & Early yield & Total yield $\mathbf{( k g / \mathbf { ~ m } ^ { 2 } \mathbf { ) }}$ \\
\hline Bottle Gourd & 2.083 & 5.125 & 2.250 & 7.708 \\
Super Shintosa & 2.083 & 7.083 & 2.332 & 7.875 \\
Squash 4 & 2.668 & 8.583 & 3.083 & 10.00 \\
Ferro & 3.083 & 11.668 & 3.583 & 14.750 \\
LSD at 0.05 & 0.528 & 1.68 & 2.10 & 1.980 \\
\hline
\end{tabular}

\section{4- Effect of rootstock types on some chemical characteristics of cucumber} fruits:

There were no significant differences between control plants and all rootstocks in all chemical contents (percentage of dry matter, TSS and total and reducing sugars) of cucumber fruits in summer planting, when these contents were determined 60 days after planting (Table 10). On the other hand, grafting on Bottle Gourd increased total sugars in cucumber fruits in winter season, using Ferro rootstock under the same conditions caused significant increase in the percentage of dry matter and reducing sugars as compared with non grafted plants (Table 11).

Table 10: Effect of grafting on the percentage of dry matter, total suable sugars and total and reduction sugars in cucumber fruits, 60 days after planting (summer planting, 2013)

\begin{tabular}{lcccc}
\hline Rootstock & $\begin{array}{c}\text { Fruit dry } \\
\text { matter }(\%)\end{array}$ & $\begin{array}{c}\text { TSS } \\
\%\end{array}$ & $\begin{array}{c}\text { Total sugars } \\
(\%)\end{array}$ & $\begin{array}{c}\text { Reducing sugars } \\
(\%)\end{array}$ \\
\hline Bottle Gourd & 6.89 & 6.33 & 3.59 & 3.26 \\
Super Shintosa & 8.48 & 6.17 & 4.35 & 3.23 \\
Squash 4 & 8.48 & 6.33 & 4.70 & 4.07 \\
Ferro & 9.05 & 6.17 & 4.57 & 3.43 \\
LSD at 0.05 & N.S. & N.S. & N.S. & N.S. \\
\hline
\end{tabular}

In this regard, kabeel (1999) and Abd-Alla (2002) found that grafting cucumber onto pumpkin or squash led to raise TSS\% of fruits. On the contrary, Hongliet al. (2003) recorded negative effect for grafting, where contents of soluble sugar, vit. C, amino acids particularly, glutamic and aspartic acids decreased and the contents of nitrate, tannititrable acid 
increased in the grafted cucumber on figleaf gourd (Cucurbitcificifolia) and Sintozwa(Cucurbita maxima $x$ C.' moschata). Other studies suggested that grafting (rootstock) has no significant effect on fruit dry matter and soluble sugar content of cucumber under unstressed conditions (Zhu et al., 2006a,b; Zhong and Bie, 2007).

Table 11: Effect of grafting on the percentage of dry matter, total suable sugars and total and reduction sugars in cucumber fruits, 60 days after planting (winter planting, 2013/2014)

\begin{tabular}{lcccc}
\hline Rootstock & $\begin{array}{c}\text { Fruit dry } \\
\text { matter (\%) }\end{array}$ & $\begin{array}{c}\text { TSS } \\
\%\end{array}$ & $\begin{array}{c}\text { Total } \\
\text { sugars (\%) }\end{array}$ & $\begin{array}{c}\text { Reducing sugars } \\
(\%)\end{array}$ \\
\hline Bottle Gourd & 8.09 & 6.33 & 11.96 & 3.32 \\
Super Shintosa & 8.91 & 6.17 & 10.86 & 4.17 \\
Squash 4 & 8.01 & 6.33 & 10.38 & 1.61 \\
Ferro & 10.67 & 6.17 & 9.88 & 6.87 \\
LSD at 0.05 & 1.77 & N.S. & 1.22 & 4.03 \\
\hline
\end{tabular}

\section{REFERENCES}

Abd-Alla, M. A. 2002. Effect of soil solarization, fertilizer sort and grafting on growth and productivity of cucumber crop ( Curcumis sativa, L.). Ph.D. Thesis, Fac.Agric. Kafr El-Sheikh, Tanta Univ. Egypt, PP,98.

Canizares, K. A.; J. Rodrigues; R. Goto and R. Boas. 2005. Influence of irrigation water enriched with carbon dioxide and grafting on the nutrient content of cucumber plants. Hort. Brasileira, 23 (1) : 9- 14.

Chaohong, D.; W. Xuewu; B. Chonglai; H. Tianhua and D. Liming. 2007. Influence of different rootstocks on the growth of alpine cucumber. Acta Agri. Zhejiangensis, (3): 241-244.

Colla, G., Suãrez, C.M.C., Cardarelli, M., Rouphael, Y. 2010a. Improving nitrogen use efficiency in melon by grafting. HortScience, 45: 559565.

Colla, G., Rouphael, Y., Cardarelli, M., Salerno, A., Rea, E. 2010b. The effectiveness of grafting to improve alkalinity tolerance in watermelon. Environ. Exp. Bot, 68: 283-291.

Colla, G., Rouphael, Y., Leopardi, C., Bie, Z.2010c.: Role of grafting in vegetable crops grown under saline conditions. - Sci. Hort. 127: 147155 ,.

Crinò, P., Lo Bianco, C., Rouphael, Y., Colla, G., Saccardo, F., Paratore, A. , 2007: Evaluation of rootstock resistance to fusarium wilt and gummy stem blight and effect on yield and quality of a grafted 'Inodorus' melon. HortSci.,42: 521-525.

El-Aidy, F.; N. Hassan; E. Metwally and M. A. Abd-Alla. 1996. Effect of grafting on vegetative growth and yield of cucumber plants under plastic greenhouse in North Delta. $1^{\text {st }}$ Egypt-Hung. Hort. Conf., Kafr El-Sheikh, Egypt, 15-17 Sept. 2: 118-122. 
Eguchi, H. and M. Koutaki. 1986. Analysis of soil temperature effect on transpiration by leaf heat balance in cucumber, cucurbita and their grafted plants. Biotronics. 15: 4554.

El-Semellawy, E. M. H. 2005. Effect of grafting on growth and yield of watermelon plants grown under low plastic tunnels in Baltiem District. Ph.D. Thesis, Fac. Agric., Kafr El-Sheikh, Tanta Univ. Egypt, 211p.

Flores, F.B., Sanchez-Bel, P., Estan, M.T., Martinez-Rodriguez, M.M., Moyano, E., Morales, B., Campos, J.F., Gracia-Abellan, J.O., Egea, M.I., Fernandeze-Garcia, N., Romojaro, F., Bolarin, M.C., 2010. The effectiveness of grafting to improve tomato fruit quality. Sci. Hort. 125, 211-217.

Frie, E.; K. peye and E. Schultz . 1964. Phosphorus determination Schwa, L d wirtschaft for change. Heft, 3: 318-328.

Gomez, K. A. and A. A. Gomez. 1984. Statistical Procedures for Agricultural Research 2 Ed. John Wilelysens. Inc-New York.

Huaifu, F, G. Shirong: Z. Runhua: L. Nana: C. Congcong and D. Changxia.2006. Effects of grafting on growth and physiological metabolism in cucumber seedlings under hypoxia stress. Acta Hort. Sinica, 33(6) : 1225-1230.

Heuvelink, E., Kierkels, T., 2005. Onderstam snel alternatief voor langzame veredeling. Onder Glas 8, 28-29.

Hongli, L. W. Minglin: Y. Xianchang: W. Huasen: G. Junjie and Y. Chao .2003. Effect of different scions/rootstocks on quality of cucumber fruits in greenhouse. Sei. Agri. Sinica. 39 (8) : 1611-1616.

Hong, M. M: X. Dong: W. M. Wang and X. I. Su. 1997. A comparative study on different grafting methods of cucumber. Acta Agric. Shanghai, 13(1): 87-89.

Kabeel, S. M. 1999. Effect of some cucurbits rootstocks on growth, yield and resistance to some soil pests of cucumber under plastic houses. Ph.D. Thesis, Fac. Agric., Moshtohor, Zagazig Univ. Egypt, 79p.

Kawaide, T. 1985. Utilization of rootstocks in cucurbits production in Japan. Jap. Agric., Res. Quarterly (JARQ). 18(4): 284-289.Kim, S. E. and J. M. Lee. 1989. The effect of grafting and fertilizers on growth and mineral contents of leaves of cucumber (Cucumis sativus, L.) J. Korean. Soc. Hort. Sci. 7: 46-47. (C.F. Hort. Abst. 59:7413).

King, E. J. 1951. Micro Analysis in Medical Biochemistry. $2^{\text {nd }}$ ed. Churchill, London.

Jackson, M, L, 1967. Soil Chemical Analysis.Prentic Hall of India, Private Limited,New Delhi, 115p.

Koch, F. C. and T. L. McMeeking. 1924. The chemical analysis of food and food products. J. Amer. Chem. Soc,46: 2066.

Lee, J. M. 1989. On the cultivation of grafted plants of cucurbitaceous vegetables. J. Korean. Soc. Hort. Sci, 30(3): 169-179.

Lee, J.M., Kubota, C., Tsao, S.J., Bie, Z., Hoyos Echevarria, P., Morra, L., Oda, M., 2010. Current status of vegetable grafting: diffusion, grafting techniques, automation. Sci. Hort. 127, 93-105. 
little, T. A. and F. J. Hills. 1672. Statistical Methods in Agriculture Research. Univ. of Calif. Davis, 242p.

Lowther, G. R. 1980. Use of a single H2SO4-H202 digest for the analysis of pinus radiate needles. Comnun. Soil. Sci. Plant Analysis, 11: 175-188.

Malik, C.P. and M.B.Sinngh. 1980. Plant enzymology and histoenzmology.A Text. Manual, Kalyani publishers, New Delhi.

Mounir, M. M. 1965. Physiological and anatomical response of fruits and plant of watermelon grafted on different cucurbita species. PhD. Thesis, Fac. Agric, Ain Shams Univ. Cairo. Egypt,172p.

Nijs, A. P. 1980. The effect of grafting on growth and early production of cucumbers at low temperature. Acta Hort, 118: 57-63.

Nijs, A. P. 1984. Rootstock scion interaction in the cucumber: Implications for cultivation and breeding. Acta. Hortculturae,156:53-60.

Pregel, F. 1945. Quantitative Organic Micro Analysis. 4th ed. J. \& A. Churchill, Lotoi, London

Rivard, C.L., Louws, F.J. 2008. Grafting to manage soilborne diseases in heirloom tomato production. HortSci. 43: 2104- 2111.

Rouphael, Y., Schwarz, D., Krumbein, A., Colla, G., 2010. Impact of grafting on product quality of fruit vegetables. Sci., Hort.,127, 172:179.

Rouphael, Y., Cardarelli, M., Rea, E., Colla, G. 2008a.: Grafting of cucumber as a means to minimize copper toxicity. Environ. Exp. Bot. 63: 49-58,.

Rouphael, Y., Cardarelli, M., Colla, G., Rea, E. 2008b. Yield, mineral composition, water relations, and water use efficiency of grafted mini watermelon plants under deficit irrigation. HortSci. 43: 730-736,

Savvas, D., Papastavrou, D. Ntatsi, G., Ropokis, A., Olympios, C., Hartmann, H., Schwarz, D. , 2009. Interactive effects of grafting and Mn-supply level on growth, yield and nutrient uptake by tomato. HortSci. ,44: 1978-1982

Schwarz, D., Rouphael, Y., Colla, G., Venema, J.K. 2010.: Grafting asa tool to improve tolerance of vegetables to abiotic stresses: thermal stress, water stress and organic pollutants. - Sci. Hort. 127: 162-171,

Shimada, N. and M. Moriya. 1977. Plant nutrition studies on the grafting of garden crops. II. Nutrient absorption by grafted plant (cucumber and pumpkin) in culture solutions with varying nutrient levels. J. Sci., Soil and Manure, Japan. 48: 396-401.

Tsambanakis, J. 1984. Grafting cucumber hybrids on the rootstock Cucurbita ficifolia. Proc. Of 3rd Conf. on Protected Veg. and flowers, Heralction, Greece. (C. F. Hort. Abst. 57: 2007)

Visser, D.L. and A. p. Nijs. 1987. Prospects of better seed quality and grafting performance in the cucumber rootstock. Sicyos angulatus Prophyta. 41: 43-45.(C. F. Plant Breed. Abst. 57: 6511)

Weng, Z. X.; B. D. Li and D. X. Feng. 1993. Study on enhancement of cucumber resistance and yield by grafting on Cucurbita ficifolia. Chinese Veg. 3: 11-15. (C. F. Rev. Plant Path. 74: 1575). 
El-Sayed, S.F. et al.

Zhong, Y.Q., Bie, Z.L., 2007. Effects of grafting on the growth and quality ofcucumber fruits. Acta Hort. 761, 341-347.

Zhu J, Bie ZL, Li YN. 2006: [Evaluation of salt resistance of cucumber at seed germination and rootstock-seedling stages. Sci. Agri. Sin., 39, 772-778 (in Chinese with English summary).

Zhu, J., Bie, Z.L., Xu, R., Tang, M., Pei, Y., 2006b. Effects of different rootstocks on the growth, yield, and quality of cucumber fruits. J. Huazhong Agric. Univ. 25, 668-671

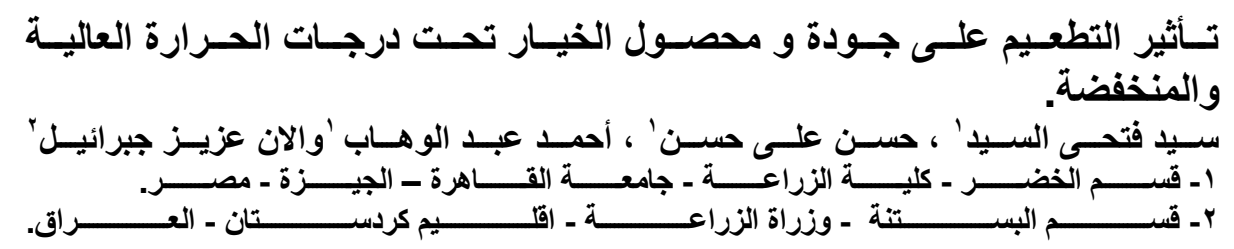

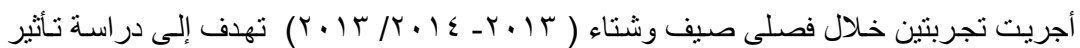

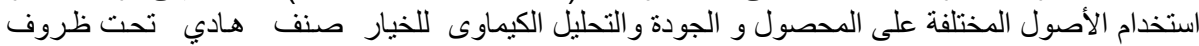

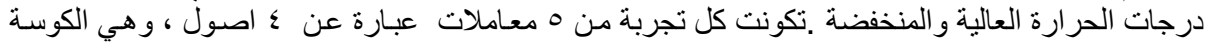

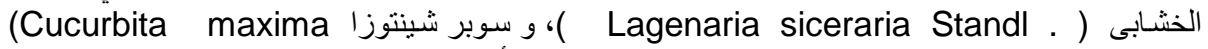

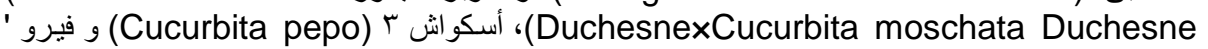
(C. maxima × C. moschata)

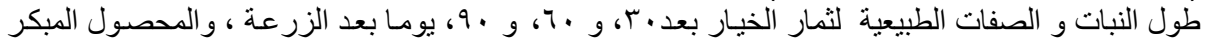

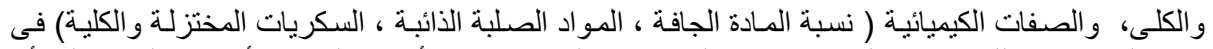

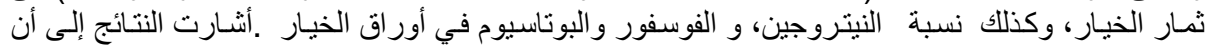

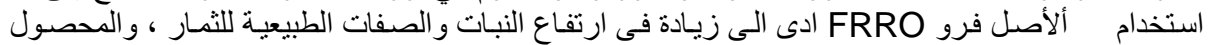

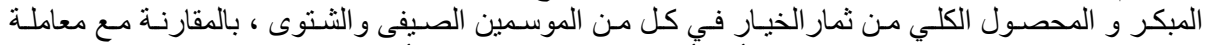

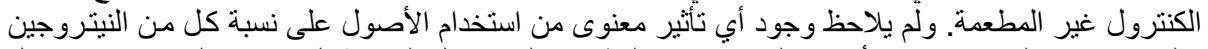

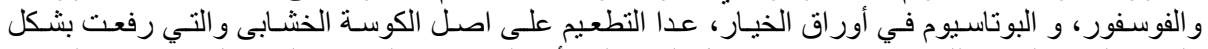

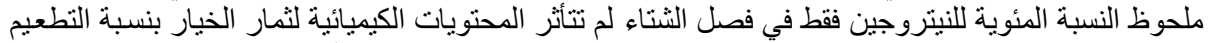

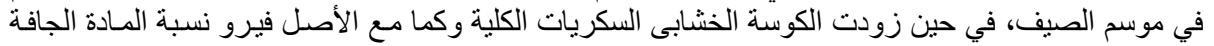
و السكريات المختزلة في الثمار فى فصل الثنتاء مقارنة مع النباتات غير المطعومة.

قام بتحكيم البحث

كلية الزراعة - جامعة المنصورة

أ.د/ سمير محمود العفيفى

كلية الزراعة - جامعة القاهره

أ.د/ خالد السيد عبد العاطى 